\title{
Uncovering the Sexual/Gender Politics: a Study of Devdutt Pattanaik's the Pregnant King
}

\author{
Somrita Dey \\ Vivekananda Mahavidyalaya, Burdwan, India
}

\begin{abstract}
The concerned paper is an exploration of society's repeated attempts to uphold the malelfemale and masculine/feminine binary by silencing those human conducts that deviate from the path of supposed normalcy, as presented in Devdutt Pattanaik's novel. The affirmation of the non-existence of all forms of marginal sexualities, and those human tendencies that violate the gender stereotypes, is imperative to the preservation of the binary structure and hence their suppression. The paper attempts to delineate how even the slightest violation of sexual and gender norms are denied expression and ruthlessly silenced.
\end{abstract}

Keywords: Gender roles, Marginal sexuality, Society, Suppression.

\section{Introduction}

...thou shalt not speak, thou shalt not show thyself... ultimately thou shalt not exist, except in darkness and secrecy...do not appear if you don't want to disappear. [1]

Society since time immemorial has endeavoured to suppress voices that refuse to subscribe to the existing social codes of conduct. Human beings perceive the world in dyads of binary opposition -good/bad, white/black, man/woman so on and so forth, and whatever fails to conform to this binary structure is relegated to the margins and in due course dexterously obliterated. Devdutt Pattanaik's The Pregnant King is an exploration of society's recurrent efforts to silence all human behaviours that register either an implicit or explicit violation of this structure vis-à-vis the binary of male/female and of masculinity/femininity, by default. There is, however, no inherent, intrinsic relationship between the two dyads. Simone de Beauvoir famously observes that one is not born, but rather becomes, a woman, implying, the creation of the gendered identity is not a biological phenomena but a socio cultural concoction, one externally acquires through "repeated stylization of the body" [2]. But society sees gender identity to be an inseparable integrant of one's anatomical constituents, mutually inclusive, where there exists one to one correspondence between biological sex and its respective gender- a male is undeniably "masculine" and woman " feminine". This acculturation of the body to its allotted gender however incorporates what Butler calls "punitive consequences", that is, "those who fail to do their gender right are regularly punished" [3]. In the concerned novel several such cases are detailed where one's failure to adhere to the corresponding gender role is duly punished and inevitably silenced.

The novel centers round Yuvanahsva, the pregnant king who accidentally slips onto the grey area between fatherhood and motherhood. In the course of doing so the novel narrates several other tales that similarly explore the problematic of sex and gender as also the blatant suppression of voices that swerve away from socially affiliated codes of conduct. The novel for instance, narrates Arjuna's experience as an eunuch Brihanalla, in the court of king Virat, as also the story of Somvat who metamorphoses into Somvati, of Aruni, the god of dawn, who masqueraded as a woman and was forced to accept the seed of both Indra and Surya, of Ila, who experienced both fatherhood and motherhood, whose memory as the bards claim "was restricted to the rituals of the temple" [4] and never seen as history. As the basic trajectory of the story of Yuvanashva, goes, he accidentally drinks a magic potion meant to impregnate his wives and as a result himself conceives a child that begins to grow in his left thigh. From here begins his trial, his desperate attempts at negotiating with his fractured sexual and gender identity, and his relentless struggle against society's repeated efforts at camouflaging the fissures to affirm its "non existence" which by implication is "an admission that there was nothing to say about such things, nothing to see, and nothing to know" [5]. Asanga, his doctor relegates his pregnancy to the domain of the unnatural, as something altogether otherworldly, thereby ascribing to it the status of non-human experience. Even Yuvanashva's mother, Shilavati treats his pregnancy disparagingly. In utter disgust of the life that grows within his son, she strips it off, of its humanity and decides to kill it:

What if it is a monster? A parasite... Cut it out.

Get the monster out of his body. [6]

It is as if, its very status of being created inside the body of a man in arrant violation of established sexual norms disqualifies it for the "human" identity, hence should be eternally silenced.Yuvashva too ,faces persecution in the hands of his family members. In the first instance, he is denied the knowledge of having given birth to a child and finally when he comes to know about it, he is denied access to the child. On Shilavati's strict 
instructions the child is taken to the woman's quarter and its door is closed against Yuvanashva to "Let motherhood remain with the women" [7], in faithful adherence to the heteronormative codes. Heteronormativity, as Jillian Todd Weiss puts it, is a "power to define our place in the hierarchy, to control those below us, and to be controlled by those above us" and "To step out of the hierarchy is to lose power and control, to lose congruity. To separate sex and gender is to disassemble the coiled binary structure from which our power, control, and sense of congruity derives." [8] Hence the prioritization of prescribed gender roles over individual lives, owing to which Yuvanashva is not allowed to give suck to his child though it, suffers immensely due to lack of proper nursing. Finally Yuvanashva is allowed his wish, but only in secrecy.

Yuvanashva desperately seeks historical instances to resolve the dichotomy he experiences between maternal and filial emotions but history that "organizes...distributes...orders...arranges... establishes series"[9] rarely documents such singular cases that resists its homogenizing and universalizing tendencies, and even if it does, concludes it in the rejection of the concerned persons, as in case of the two children born of Aruni, the god of dawn , who were given away to the monkeys, implying as the bards reveal " children born of a man are fit only to be raised as monkeys"[10] .Their very lineage being inimical to the male female binary ,make them unfit for human society. To avoid a similar fate with regards to the little prince Mandhata, tales are fabricated at his felicitation ceremony to facilitate his public acceptance.Simantini pertinently points out "people see what they are shown" thus validating Foucault's claim that even "the last glimmer of truth is conditioned by politics" [11]. Truth, Foucault observes "isn't the reward of free spirits, the child of protracted solitude, nor the privilege of those who have succeeded in liberating themselves"[12], on the contrary every society has its distinct "regime of truth" [13] engendered and sustained as the embodiment of fact. History thus is not a chronicle of absolute truths, but realities that have been tampered with for social convenience. Facts that have the potential of jeopardizing the very foundations of society if not distorted are at best systematically effaced from records, thereby affecting what Foucault calls suppression through oblivion. The bards claim to have forgotten the story of Bhangashvana, the man who was addressed both as father and mother by his children- the story that they actually knew but pretended ignorance only because, as they themselves revealed, such things are never appreciated as truth but treated as mere fanciful constructs, a story supposed to be known by only Bhishma who passed it on to the Pandavas on his deathbed. Desperate to validate his position, Yuvanashva attempts to extract it from Arjuna, with which aim he agrees to let pass the horse of Ashwamedha yajna through his kingdom only on knowledge of the tale. Arjuna refuses any knowledge of it and remarks "Some stories are not meant to be remembered" [14], but on Yuvanashva's provocation ends up recounting his own experiences as Brihanalla. As he himself confesses, he wishes to obliterate it from his memory: "Please don't ask me to remember that year", comes his earnest exhortation, "... It is terrible to appear as a woman and still have a man's heart" [15]. A society that thrives on the fallacy of exhaustive hypothesis, vis-à-vis gender, provides no room for the innumerable spectrum of possibilities that tend to lie between two mutually exclusive constructs of masculine and feminine. This compartmentalization enforces strict conformance to actions and expressions deemed suitable for the respective sex, so much so that violation of the same often lead to infamy.Arjun recounts how Uttara, the son of Virat, objected to his sister's inclination towards archery claiming it to be a masculine feat, to which Uttari retorted that his brother's penchant for dance should also be condemned, given its status as pretty feminine. Archery for male and Dance for female can seen as, what Butler calls "the various acts of gender" which "create the idea of gender" without which "there would be no gender at all" [16]. Hence to pursue their desires, they were sworn to secrecy by each other for as Butler asserts "punishments ... attend not agreeing to believe in them" [17]. Thus their predilections being disruptive of prescribed social codes are barred from public knowledge. Secrecy was also maintained with regards to Krishna's temporary appropriation of a female body, Mohini, during the Kurukshetra war: "Sanjaya who saw the whole war with his mind's eye...did not see this" [18], reveals Arjun. Society that considers the man woman categorisation "neither negotiable nor transferable" [19] refuses room to any knowledge of such flux of sexual identity.

So much for self imposed speechlessness. But for those who refuse voluntary submission, society has its own way of choking their voices. When Yuvanashva, for instance, expresses his desire of being addressed as mother by Mandhata, Simantini warns him of dire consequences. She cautions him against scandal, then dangles the bait of kingship, positing his parental status as mother, which is strictly feminine, against his social status as king, indubiously masculine. When Yuvanashva says he would like to be both, Simantini argues that such shuffling of gender roles is forbidden, owing to their social construction as mutually exclusive where functioning in one entails a specific sexual identity that invariably precludes the person from roles assigned to the opposite sex:

To be mother you must be a woman. Are you saying you are a woman Arya? If you are a woman you have no right to sit on the throne.[20] 
This is the very reason why Yama's account book, as Yuvanashva later comes to know, has no record of his mother, Shilavati's identity as an efficient ruler who goaded their kingdom to prosperity on the death of his husband and his father-in-law, as that would amount to transgression of gender stereotypes. She is described only in her feminine roles as "the dutiful daughter of Ahuka, loving sister of Nabhaka, obedient wife of Prasenjit and doting mother of Yuvanashva"[21]. Simantini, his wife, quite pertinently implores Yuvanashva, "Let the world see you as it wants to see you. A great king, with three wives and two sons. Virile and strong and obedient... Be a father. Leave motherhood to me. I am your wife" [22]. What Simantini posits, to say in Foucauldian terms, is "the legitimate and procreative couple" [23]. Foucault writes with respect to the couples deemed legitimate in the Victorian era:

The couple imposed itself as model, enforced the norm...

Nothing that was not... transfigured by it could expect sanction or protection. Nor did it merit a hearing. It would be driven out, denied, and reduced to silence... it had no right to exist and would be made to disappear upon its least manifestation...[24]

Still when Yuvanashva refuses to relent ,Simantini cautions him against the punishments that await such obstinate perverts like him, a fate that he himself effectuated with regards to Sumedha and Somvati, and a fate from which even he can't escape unsigned if situation so demands.

At this juncture the story of Sumedha and Somvati needs mention. Somvati was initially Somvat, a young Brahmin boy. Sumedha and Somvati's marriage were fixed with the two daughters of a woman named Kaveri. The woman however had one condition. They were required to get a cow for themselves. While Sumedha managed to get one, Somvat was in a mess. To get out of this problem, the two friends hit upon a plan. They set out for the cow giving ceremony of Yuvanashva posing as Brahmin couples. Their fraud was detected and they were thrown into prison. Their crime was heinous as they tried to hoodwink the royal family, but more terrible was their faking as a "married couple" being of the same biological sex. On the night of their incarceration, Somvat terribly lamented his manhood. He thought that had he not been a man they would have been let off with minor punishment. At that instance, Sthunakarna, a yaksha came to Somvat's rescue and took away his manhood. But next morning the situation, however, worsened. When Somvat's transformation came to light he was even more vilified. Her womanhood, though glaringly explicit, was outright rejected owing to its negation of the biological sex with which he was born. Yuvanashva proclaims "The dharma- shastra say that roles and responsibilities of a Manava are determined at birth by his biology... You are born a man...You are forever a man" [25]. The sexual identity with which one is born becomes the sole determinant of the gender roles one would be performing in society, by which requirement Somvati is to marry a woman. But given Somvati's present sexual identity, it is unacceptable to her. She on the contrary goes on asserting her womanhood and her conjugal nexus with Sumedha. Disregarding the repeated warnings of others when they refuse to surrender their marital status, they are sentenced to death by Yuvanashva. Society that treads on neat paths has no provision for accommodating such inflexible identities.

Hence Simantini's warnings "The world must not know that you are an aberration. They will cast you into the same pyre into which you cast those two boys."[26]. It is quite ironical that Yuvanashva who has so vehemently perpetuated its workings, himself falls within its vicious trappings . Simantini reminds him of the ultimate fate of such unbending sexual deviants like him, a hermaphrodite, part of the peripheral sexualities, considered "criminals, or crime's offspring, since their anatomical disposition, their very being, confounded the law that distinguished the sexes and prescribed their union" [27].

However, Yuvanashva's final rejection comes at the hands of his son Mandhata, that very son for whom he was ever ready to put his social reputation at stake. In firm assertion of prevalent gender stereotypes he vehemently dismisses Yuvanashva's appropriation of maternal identity. He desperately tries to affirm its non existence:

Nothing had changed. The conversation in the maha-sabha had not taken place. He tried hard to forget it.[28]

So much is Mandhata's obsession with social codes that even when Yuvanashva decides to renounce the world , never for once does he budge to address him as "mother", which would in all probability had halted his march.Yuvanashva's ostracization is complete. After years of self imposed silence finally when he utters the truth he is publicly dismissed as mad. Even Shilavati, who has full knowledge of the truth, to safeguard the reputation of the royal family join hands with others in confirmation of his son's psychic derangement. The bards are right to point out, such stories as Yuvanashva's never get the attestation of truth and will "soon be forgotten" [29], just as the story of Ila. At this juncture the bards finally reveal to him the story of Ila or Bhangashavana as they deem his mind to be ripe enough for accepting the truth that the story engenders: 
We have one last story for you... The story we never told you. The story we never tell. The story that has never been told, except by Bhisma to the Pandavas before he died. The one that Arjuna said he forgot.. We finally have an audience who will not laugh... [30]

As the story runs, Ila was born a man but under the effect of a very strange spell, turned into a woman. When he begged off Shiva to undo the spell, it being incapable of revocation was modified. It was decreed that Ila's masculinity would wax and wane with the moon, implying, he would by turn manifest the traits of both the male and the female: "He would be all male on full- moon days and all female on new-moon nights" [31]. Accordingly Ila became both father and mother. But just as Aruni's children, he/she too was bereft of his humanity. Only the former were accorded the status of beasts, while Ila was escalated to Divinity. ILA, the human, got ousted by Illeshwara the god/goddess, thus getting circumscribed within the constricted pen of rituals, in outright exclusion from human history. The bards pertinently point out, that just like ILA, Yuvanashva's story too would efface from human memory.

\section{Conclusion}

Thus Pattanaik's novel can be said to be a powerful delineation of society's repeated attempts at silencing disparate sexualities that confound the sexual and gender binaries. The strategies employed are various - ranging from voluntary submission to forceful oblivion and punitive measures, but all are aimed at sustaining the existing power structure, motivated by, as Foucault says "one basic concern...to constitute a sexuality that is economically useful and politically conservative" [32].In the course of exploring the sexual and gender politics, the nature of power as extolled by Foucault is also fore grounded. Foucault maintains that the exercise of power is not a unidirectional traffic "extending from the top down", nor is there an "allencompassing opposition between rulers and ruled". Power is rather, the " complex strategical situation in a particular society”, " exercised from innumerable points”[33], which is why, not only commoners , like Sumedha and Somvati but also people at high places like Yuvanashva, the very king, finds himself at its mercy.

\section{References}

[1] Michel Foucault, The Will to Knowledge (Penguin Books Ltd, UK,2006)

[2] Judith Butler, Performative Acts and Gender Constitution: An Essay in Phenomenology and Feminist Theory, Theatre Journal,40(4), 1988, 519-531.

Ibid

Devdutt Pattanaik, The Pregnant King (Penguin Books India Pvt. Ltd, New Delhi, 2008).

Michel Foucault, The Will to Knowledge (Penguin Books Ltd, UK, 2006).

Devdutt Pattanaik, The Pregnant King (Penguin Books India Pvt. Ltd, New Delhi, 2008).

Ibid

Jillian Todd Weiss, The Gender Caste System: Identity, Privacy, and Heteronormativity, Law \& Sexuality,(10)123, $2001,1-64$.

Michel Foucault, The Will to Knowledge (Penguin Books Ltd, UK, 2006).

Devdutt Pattanaik, The Pregnant King (Penguin Books India Pvt. Ltd, New Delhi, 2008)

Michel Foucault, The Will to Knowledge (Penguin Books Ltd, UK, 2006).

Ibid

Michel Foucault, Power/Knowledge: Selected Interview and Other Writings 1972-1977 (Harvester Press, Brighton, 1980).

Devdutt Pattanaik, The Pregnant King (Penguin Books India Pvt. Ltd, New Delhi, 2008).

Ibid

Judith Butler, Performative Acts and Gender Constitution: An Essay in Phenomenology and Feminist Theory, Theatre Journal,40(4), 1988, 519-531.

Ibid

Devdutt Pattanaik, The Pregnant King (Penguin Books India Pvt. Ltd, New Delhi, 2008).

Aaron H. Devor, FTM: Female-to-Male Transsexuals in Society (Indiana University Press, Bloomington,1997).

Devdutt Pattanaik, The Pregnant King (Penguin Books India Pvt. Ltd, New Delhi, 2008).

Ibid

Ibid

Michel Foucault, The Will to Knowledge (Penguin Books Ltd, UK, 2006).

Ibid

Devdutt Pattanaik, The Pregnant King (Penguin Books India Pvt. Ltd, New Delhi, 2008).

Ibid

Michel Foucault, The Will to Knowledge (Penguin Books Ltd, UK, 2006).

Devdutt Pattanaik, The Pregnant King (Penguin Books India Pvt. Ltd, New Delhi, 2008).

Ibid

Ibid

Ibid

Michel Foucault, The Will to Knowledge (Penguin Books Ltd, UK, 2006).

Ibid 